\title{
Referencia:
}

Padrón Moctezuma, M. S., Ochoa-Vásquez, M. Á., Ramírez-Montoya, M. S. (2016). Net Generation Features that Enhance Mobile Learning. In. L. Briz-Ponce, J. A., Juanes-Méndez, F. J. García-Peñalvo

(Eds.), Handbook of Research on Mobile Devices and Applications in Higher Education Settings. Chapter 5. Hershey, PA: IGI Global. ISBN13: 9781522502562, ISBN10: 1522502564, EISBN13: 9781522502579. DOI: 10.4018/978-1-5225-0256-2. Disponible en: http://www.igi-global.com/chapter/net-generationfeatures-that-enhance-mobile-learning/159372

\section{Handbook of Research on}

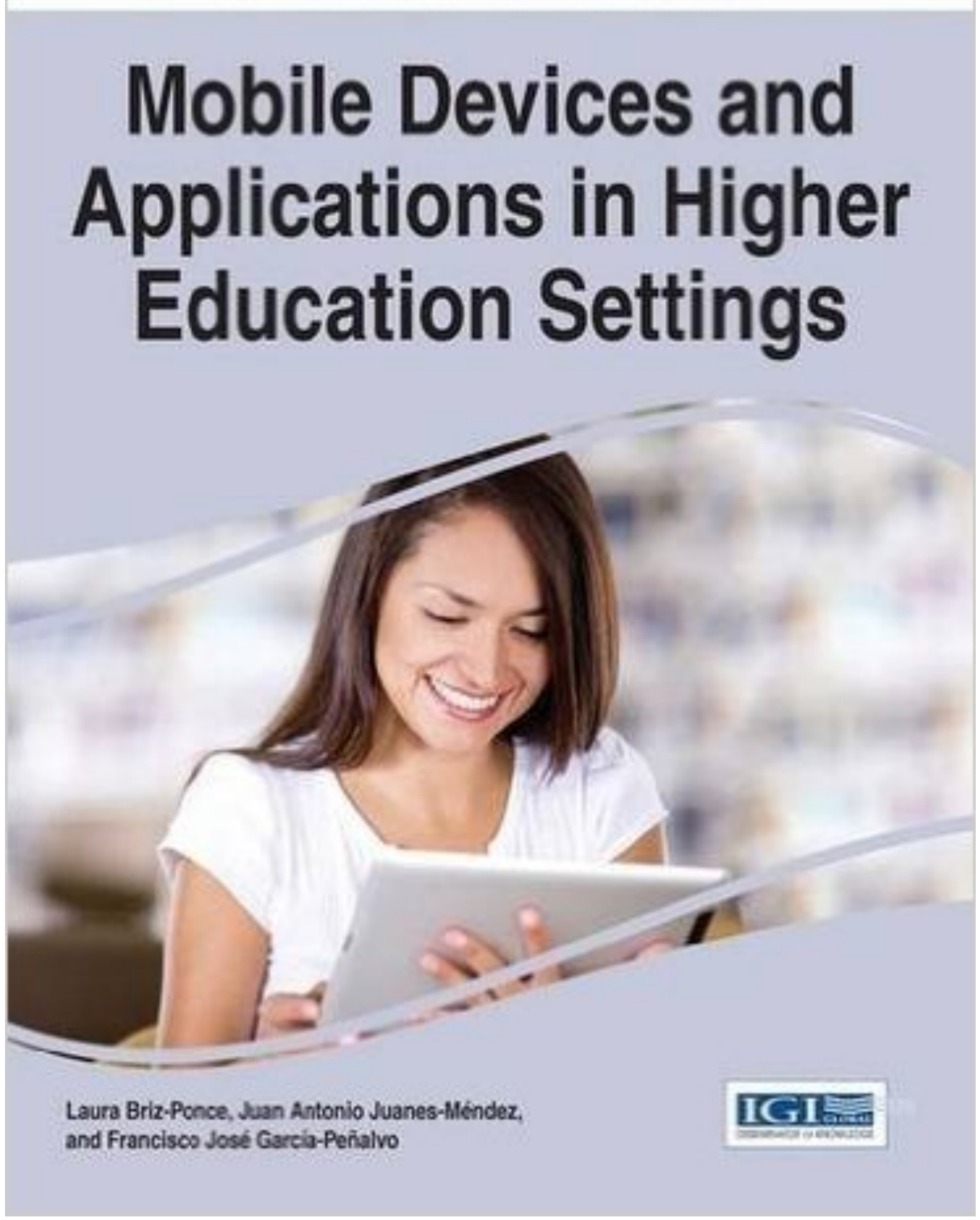




\section{Table of Contents}

\section{Preface}

\section{Acknowledgment}

\section{Chapter 1}

Development Challenges of a Full Integrated app in Higher Education

Prof. Anabela Sousa Pereira, University of Aveiro, Portugal

Prof. António Moreira, University of Aveiro, Portugal

Dr. Paulo Chaló, University of Aveiro, Portugal

Prof. Luís Sancho, University of Aveiro, Portugal

Dr. Ana Varela, University of Aveiro, Portugal

Dr. Carla Oliveira, University of Aveiro, Portugal

\section{Chapter 2}

Do Mobile Technologies have a place in Universities? The TAM Model in Higher Education José Carlos Sánchez Prieto, University of Salamanca, Spain

Susana Olmos-Migueláñez, University of Salamanca, Spain

Francisco José García-Peñalvo, University of Salamanca, Spain

\section{Chapter 3}

Information Sharing and Communications with Mobile Cloud Technology- Applications and Challenges Shantanu Pal, the University of St. Andrews, UK

\section{Chapter 4}

Framework to Develop a Learning Analytics System for Smartphone Blended Learning Environment Mazharuddin Syed Ahmed, University of Canterbury, New Zealand.

\section{Chapter 5}

Net Generation Features that Enhance Mobile Learning

María Soledad Padrón Moctezuma, Sistema Educativo Estatal Regular, Mexico

Miguel Ángel Vasquez Ochoa, Universidad Estatal de Sonora, Mexico

María Soledad Montoya Ramírez, Tecnológico de Monterrey, Mexico

\section{Chapter 6}

Academic Libraries' Mobile Initiatives and Research from 2010 to the Present: Identifying Themes in the Literature

Barbara Blummer, Center for Computing Sciences, US Jeffrey M. Kenton, Towson University, US 


\section{Chapter 7}

The Global Change App: The Creative Transformation of Scientific Research

Stephanie B. Borrelle, Auckland University of Technology, New Zealand

Dr. Stanley Frielick Auckland University of Technology, New Zealand

Dr. Roman Asshoff, Zentrum für Didaktik der Biologie, Germany

Dr. Sebastian Leuzinger, Auckland University of Technology, New Zealand

\section{Chapter 8}

Virtual Territorial Heritage in Education through mLearning resources: Cities of Salamanca Spain and Santiago of Chile

Jorge Joo Nagata, Universidad Metropolitana de ciencias de la Educación, Chile Dr. José Rafael García-Bermejo Giner, University of Salamanca, Spain

Dr. Fernando Martínez-Abad, University of Salamanca, Spain

\section{Chapter 9}

A research contribution to the analysis of mobile devices in higher education from medical students' point of view

Laura Briz-Ponce, University of Salamanca, Spain

Juan Antonio Juanes-Méndez, University of Salamanca, Spain

Francisco José García-Peñalvo, University of Salamanca, Spain.

\section{Chapter 10}

Bespoke Mobile Application Development: Facilitating Transition of Foundation Students to Higher Education.

Nevan Bermingham, Dublin Institute of Technology, Ireland

Dr. Mark Prendergast, Trinity College Dublin, Ireland

\section{Chapter 11}

The Effect of using Mobile Devices on Students' Performance in Writing Marielle Patronis, Zayed University, United Arab Emirates

\section{Chapter 12}

Student Use of Cell Phones to Conduct Real-Time Polling

Dr. Sheri Stover, Wright State University, US

Dr. Carol Patitu, Wright State University, US

Dr. Roxanne DuVivier, Wright State University, US

\section{Chapter 13}

Universities' Point of view to Introduce Mobile Devices in their Classrooms': Redefining

Education using a Common Mobile Platform: The Journey through implementation

Dr. Victoria Cardullo, Auburn University, US

LeNessa L. Clark, Auburn University, US

\section{Chapter 14}

Mobile Journalism, Cellphilms and the Use of the StoryMaker Multimedia Software at a Zimbabwean Media Training University Nhamo Anthony Mhiripiri, Midlands State University, Zimbabwe

Oswelled Ureke, Midlands State University and University of KwaZulu, Zimbabwe and South Africa 


\section{Chapter 15}

STUMP: a model for the adoption, implementation and use of m-learning or e-learning platform.

Nana Kofi Annan, Wisconsin International University College, Ghana

\section{Chapter 16}

The Impact of Social Media on Instruction in Higher Education

Dr. Pamela A. Lemoine, Columbus State University, US

Dr. Paul Thomas Hackett, Columbus State University, US

Dr. Michael D. Richardson, Columbus State University, US

\section{Chapter 17}

Mobile Learning among Students and Lectures in the Developing World: Perceptions Using the UTAUT Model.

Lenandlar Singh, University of Guyana, Guyana

Dr. Troy Devon Thomas, University of Guyana, Guyana Kemuel O. Gaffar, University of Guyana, Guyana Dwayne Renville, University of Guyana, Guyana

\section{Chapter 18}

Engaging Students to Learn Physics and Mathematics through Short High Quality M-Learning Resources: Design and Implementation Recommendations

Dr. Luis Neri, Tecnologico de Monterrey, Mexico

Dr. Julieta Noguez, Tecnológico de Monterrey, Mexico Jessica Morales Whitney, Pfizer, Mexico

Gerardo Aguilar-Sanchez, Tecnologico de Monterrey, Mexico

\section{Chapter 19}

Applied competences for students by using m-learning devices in Higher Education:

Knowledge, skills and attitudes José Alberto Herrera, Tecnologico de Monterrey, Mexico, Dr. Darinka del Carmen Ramírez Hernández, Tecnológico de Monterrey, Mexico Dr. Maria Soledad Ramirez, Tecnologico de Monterrey, Mexico

\section{Chapter 20}

Exploring the use of mobile devices and applications to support Field Experience in Teacher Education Courses

Dr. Yiu-chi LAI, The Hong Kong Institute of Education, China

Dr. Pui-wan Pamela LEUNG, The Hong Kong Institute of Education, China

Dr. Tak-wah WONG, the Hong Kong Institute of Education, China Tze-

leung Raymond YUEN, The Hong Kong Institute of Education, China

\section{Chapter 21}

Instructor Perceptions and Intentions to Use a Tablet PC for Mobile Learning in a Ghanaian University: An Exploratory Case Study

Dr.Stephen Asunka, Ghana Technology University College, Ghana

\section{Compilation of References}

\section{About the Contributors}




\title{
Chapter 5 \\ Net Generation Features that Enhance Mobile Learning
}

\author{
María Soledad Padrón Moctezuma \\ Sistema Educativo Estatal Regular, Mexico \\ Miguel Angel Vasquez Ochoa \\ Universidad Estatal de Sonora, Mexico \\ María Soledad Montoya Ramírez \\ Tecnológico de Monterrey, Mexico
}

\begin{abstract}
This chapter presents the results of research that aims to analyze the characteristics of the youth of the Net Generation that can promote learning when using mobile devices. The study was conducted in two campuses of a Mexican university in order to provide useful information for those who work with Mobile Learning. The results showed that characteristics such as communication, teamwork, decision making, positive attitudes towards technology, self-learning and collaborative work of the young Net are the ones that can be predominantly exploited to promote learning when developing Mobile Learning resources to be fully used by students with wireless mobile devices applications.
\end{abstract}

\section{INTRODUCTION}

At present, technological breakthrough has put multiple helping tools such as wired and/or wireless electronic devices at man's hands, which has gradually become an essential part of everybody's life. This has been going on for fewer than two decades and therefore, those beings born during this historical period have spawned a new generation of young people with very special characteristics and a new way of conceiving the world. These special kids are known as the Net generation and so used to handling technology in an almost innate form, which is in itself one of the many features that make them worth studying. According to Beyers (2009: 220), "the Net Generation is defined as the population of about 90 million young people who have grown up or are growing up in constant contact with digital media and have already been defined by academics as smart but impatient". They are also believed to demand results almost immediately and carry a great deal of electronic devices.

DOI: 10.4018/978-1-5225-0256-2.ch005

Copyright @ 2016, IGI Global. Copying or distributing in print or electronic forms without written permission of IGI Global is prohibited. 
